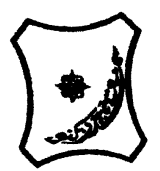

Bayero Journal of Pure and Applied Sciences, 8(1): 24 - 28

Received: January, 2015

Accepted: June, 2015

ISSN $2006-6996$

\title{
EFFECTS OF NITROGEN LEVELS AND HARVEST INTERVAL ON THE GROWTH AND YIELD OF MORINGA (Moringa oleifera Lam) IN SUDAN SAVANNA OF NIGERIA
}

\author{
${ }^{1}$ Adamu, U. A* ., ${ }^{1}$ Adamu, I. ${ }^{2}$ Bello, T. T., ${ }^{3}$ Gashua, A. G. and ${ }^{4}$ Kurawa, I. A. \\ ${ }^{1}$ Shelterbelt Research Station, Kano, Forestry Research Institute of Nigeria, ${ }^{2}$ Department of Agronomy, \\ Bayero University, Kano, ${ }^{3}$ Yobe State College of Agriculture, Gujba, ${ }^{4}$ Sa'adatu Rimi College of Education, \\ Kano. \\ * adamubnusmanu96@yahoo.com +2348066597177
}

\begin{abstract}
Field experiment was conducted under irrigation at Bayero University Kano, during 2011/2012 dry season to investigate the effects of different nitrogen levels and harvest interval on growth and leaf yield of Moringa (Moringa oleifera (Lam)). The treatments consisted of four levels of nitrogen $\left(0,50,100\right.$ and $\left.150 \mathrm{~kg} \mathrm{~N} \mathrm{ha}^{-1}\right)$ and three times of harvest interval $(2,3$, and 4 weeks). These were arranged in a split plot design with the nitrogen levels allocated to the main plots while the harvest interval allocated to the sub plots and replicated four times. The data collected were subjected to analysis of variance (ANOVA) using the general linear model of Genstat and significant different means were separated using DMRT. The result shows that applications of nitrogen significantly increased plant height, number of leaflets per plant, plant stem diameter, number of branches per plant, fresh and dry weights per plant. Generally, $150 \mathrm{~kg} \mathrm{~N}^{\mathrm{N}} \mathrm{a}^{-1}$ level gave highest values for all the growth and yield characters assessed. The highest fresh and dry total leaf yields were also obtained with $150 \mathrm{~kg} \mathrm{~N} \mathrm{ha}^{-1}$ level. Increase in harvest interval significantly increased fresh and dry leaf yields of Moringa with the highest yields obtained from 4 weeks harvest interval. Nitrogen and harvest interval interaction was found to be significant on fresh and dry leaf yields of Moringa, which indicated that high yields were supported by $150 \mathrm{~kg} \mathrm{~N} \mathrm{ha}^{-1}$ at 4 weeks harvest interval.
\end{abstract}

Keywords: Moringa, harvest interval, Nitrogen level, yield

\section{INTRODUCTION}

Moringa is a small tree with sparse foliage often planted in compound and farmlands (Keay, 1959) and belongs to the Family Moringaceae. The genus Moringa has about 13 species, and it is native to northern India. It spreads to the tropical and subtropical regions of Asia, Africa and Latin America gaining significant importance throughout the world, which is attributed to its nutritional, medicinal and industrial values (Muhammad, 2008).

The tree is found growing in most parts of Nigeria and it is locally referred to as Zogale, or Bagaruwar Makka in Hausa, in Fulfulde it is called Kabije, Gawara or Konamarade. The Yorubas call it Ewe ile and the Igbo call it Ikwe Oyibo. Moringa was probably introduced into Nigeria by Arab traders and the plant has several Arabic names as Ruwag, Alim, Halim, Shagara and Al ruwag (Auwalu, 2009).

In many parts of West Africa, Moringa leaves are considered as important leafy vegetables (Auwalu, 2009) which provides both high protein content and quality which meets the estimated amino acid requirement for children between the age of $2-5$ years (Kalb and Kuo, 2002). Leaves of Moringa are the most nutritious part of the plant, and have been used to combat malnutrition especially among infants and nursing mothers. The leaves are also good sources of protein, vitamins A, B and $\mathrm{C}$ and minerals such as calcium and iron. The leaf contains $22-35 \%$ protein together with all essential amino acids and is high in the sulphur containing amino acids, methionine and cystene, and it also contains carbohydrates at varying levels.

The protein quality of Moringa leaves rivals that of milk and eggs. Ounce by ounce Moringa leaves contain four times vitamin $A$ and betacarotene than carrot, four times calcium and two times protein than milk, more iron than spinach, seven times vitamin $C$ than oranges, and three times more potassium than bananas (Fahey, 2005) and more proteins than peas (Kalb and Kou, 2002). Moringa leaves is an excellent source of vitamins, minerals and protein perhaps more than any other tropical vegetable (Anonymous, 2008).

Moringa is propagated both sexually and asexually and it has low nutrients demand and management requirements. In Nigeria, Moringa is often grown as a live fence or a backyard tree. To put more land under cultivation as a means of increasing production to meet the growing demands of the crop will be expensive, difficult and damaging to the environment. Growers therefore need to increase their production by adopting appropriate strategies and techniques which will lead to sufficient and reliable yields without depleting the natural resource base. 
It is therefore essential to establish the best agronomic practices for cultivation and utilization of the crop. Thus, the aims of this research was to determine the optimum level of Nitrogen required for the growth and yield of the Moringa plant and also to determine the most appropriate harvest interval required for sustainable utilization of the plant.

\section{MATERIALS AND METHODS}

The experiment was conducted during the 2011/2012 dry season at research Farm of faculty of Agriculture, Bayero University, Kano (latitude $11^{0} 58^{\prime} \mathrm{N}$ and longitude $8^{0} 25^{\prime} \mathrm{E}, 457 \mathrm{~m}$ above sea level) in the Sudan Savannah ecological zone of Nigeria. The treatments combination consisted of four levels of Nitrogen (0, 50, 100 and $150 \mathrm{~kg} \mathrm{ha}^{-1}$ ) and three levels of harvest interval (2, 3 and 4 weeks). The experiment was laid out in a complete randomized block design at the growth stage but at 12 weeks after sowing (i.e. at harvesting stage) a split plot design was adopted with nitrogen levels allocated to the main plots while harvest interval was allocated to the sub plots and replicated four times.

The main plot size measured $3 \mathrm{~m} x$ $2 \mathrm{~m}\left(6 \mathrm{~m}^{2}\right)$ and was demarcated into three sub plots of $(1 \mathrm{~m} \times 2 \mathrm{~m})$ and each consisted of twenty rows of one meter length. The four inner rows were used as net plots and eight boarder rows were used for sampling purpose. An alley way of $1.5 \mathrm{~m}, 1 \mathrm{~m}$ and $0.5 \mathrm{~m}$ were left between replicate, main plot and sub plots respectively. The land was cleared and harrowed, leveled and prepared into irrigation basins, with irrigation channels provided. Two seeds were sown per hole manually at the depth of $2 \mathrm{~cm}$ which were later thinned to one seedling per stand at two weeks after sowing (2 WAS). Spacing of $20 \mathrm{~cm}$ inter row and $10 \mathrm{~cm}$ intra row was used. Nitrogen fertilizer (urea $46 \% \mathrm{~N}$ ) was used as source of nitrogen and it was applied at 3 WAS, along the side of the Moringa plant (Palada and Chang, 2003). Weeding was carried out manually by hoe three times at three weeks interval before harvesting. The plants were first harvested at 12 weeks after sowing as suggested by Grubben and Denton (2004).

The plants were cut manually with knife at $20 \mathrm{~cm}$ from the ground level to encourage side branching so as to enhances yield of subsequent harvests, and it was after the first harvest that the harvest interval of 2, 3 and 4 weeks treatments were introduced and lasted for three months. Observations were recorded on some growth, yield and yield components and the data collected were subjected to analysis of variance (ANOVA) using the general linear model of GenStat (2011). Significant treatment means were separated using DMRT (Duncan 1955).

\section{RESULTS}

Effect of nitrogen levels on vegetative growth of Moringa during the first 12 weeks.

The mean plant height, stem diameter and number of branches plant $^{-1}$ increased with time, showing significant differences $(P<0.05)$ from the $4^{\text {th }}$ WAS (Table 1). The highest nitrogen level $\left(150 \mathrm{~kg} \mathrm{ha}^{-1}\right)$ gave the highest increase in plant height, stem diameter and number of branches plant ${ }^{-1}$ followed by $100 \mathrm{~kg} \mathrm{~N} \mathrm{ha}^{-1}$ then $50 \mathrm{~kg} \mathrm{~N} \mathrm{ha}^{-1}$ while the control (0 $\mathrm{kg} \mathrm{N} \mathrm{ha}{ }^{-1}$ ) gave the lowest increase in plant height, stem diameter and number of branches plant ${ }^{-1}$. The leaflets number plant ${ }^{-1}$ fresh and dry weight plant $^{-1}$ increased with time in all treatments and were significantly different $(P<0.05)$ from the $4^{\text {th }}$ week onwards. Individual plants with higher level of nitrogen had a higher leaflets number, fresh and dry weight plant $^{-1}$ followed by the medium and lower nitrogen levels respectively, while the lowest number of leaflets, fresh and dry weight plant ${ }^{-1}$ were obtained for the control (Table 2). At $4^{\text {th }}$ WAS $150 \mathrm{~kg}$ $\mathrm{N}$ ha- ${ }^{-1}$ treatment gave highest fresh weight plant ${ }^{-1}$ while $100,50 \mathrm{~kg} \mathrm{~N} \mathrm{ha}^{-1}$ and the control were found to be statistically at par. During at same period 150 and $100 \mathrm{~kg} \mathrm{~N} \mathrm{ha}^{-1}$ produced plant that were statistically the same in terms of dry weight plant ${ }^{-1}$, followed by 50 and $0 \mathrm{~kg} \mathrm{~N} \mathrm{ha}^{-1}$.

Total Fresh and Dry Leaf Yields of Moringa

Table 3 shows the effects of nitrogen levels and harvest interval on the total fresh and dry leaf yields $\left(\mathrm{t} \mathrm{ha} \mathrm{h}^{-1}\right.$ ) of Moringa. The result revealed that the higher the level of nitrogen the higher the fresh and dry leaf yields throughout the harvest period. The highest total fresh leaf yield of $38.06 \mathrm{t} \mathrm{ha}^{-1}$ and total dry leaf yield of $10.21 \mathrm{t} \mathrm{ha}^{-1}$ were obtained with 150 $\mathrm{Kg} \mathrm{N}$ ha-1 during the harvests recorded after the initial general harvest at 12 WAS. On application of harvest interval treatment which lasted for three month, when nitrogen was held constant at $150 \mathrm{~kg}$ $\mathrm{ha}^{-1}$ each increase in number of weeks in harvest interval significantly increased leaf yields with maximum estimated yields of $46.029 \mathrm{t} \mathrm{ha}^{-1}$ and $12.317 \mathrm{t} \mathrm{ha}^{-1}$ fresh and dry leaf respectively obtained with 4 weeks harvest interval (Table 3 ).

Table 4 shows the interaction between nitrogen levels and harvest interval on total fresh and dry yields of Moringa leaf at BUK, the result indicated that there was positive and highly significant interaction between nitrogen levels and harvest interval on the total fresh and dry leaf yields and the best combination that produced the highest leaf yields was between $150 \mathrm{~kg} \mathrm{~N} \mathrm{ha-1}$ and 4 weeks harvest interval.

\section{Discussion}

The result of this study showed a significant difference of nitrogen level applied for all the growth and yield characters of Moringa measured. Nitrogen is known to be an essential nutrient necessary for stimulation of rapid vegetative growth because of its importance in photosynthesis and formation of chlorophyll, nucleic acid and amino acid (Samuel, 1980). Considering the low nutrient status of the soil of the experimental sites it is to be expected that application of nitrogen will increase the growth performance of the crop. Increase in nitrogen levels from 0 to $150 \mathrm{~kg} \mathrm{ha}^{-1}$ led to successive increase in growth characters such as plant height, stem diameter, fresh weight plant $^{-1}$, dry weights plant ${ }^{-1}$, leaflets number plant ${ }^{-1}$ and number of branches plant $^{-1}$ all were significantly affected by level of nitrogen application. 
This is in line with the findings of Oliver (2009) who recorded similar result in which best performance was obtained with NPK fertilizer (27-7-20) at $32-43$ $\mathrm{Kg}$ week ${ }^{-1} \mathrm{ha}^{-1}$ in Moringa production. The result is also similar to what was obtained by Dash and Gupta (2009) who reported to have obtained significant increase in growth characters of Moringa such as shoot height, leaves number, plant fresh and dry biomass when treated with NPK/Urea $\left(5 \mathrm{~g} \mathrm{pot}^{-1}\right)$ and SSP respectively. The result was still similar to that of Matallawa (2012) who reported to have obtained significant increase in plant height; stem diameter, leaflets number plant $^{-1}$, fresh and dry weight plant ${ }^{-1}$ in Moringa treated with NPK at different levels of 0 , 50,100 and $150 \mathrm{Kg} \mathrm{ha}^{-1}$.

Application of nitrogen was found to significantly increase fresh and dry leaf yields of Moringa throughout the harvesting period which lasted for three months and this could be attributed to the good responce of the plant to the $\mathrm{N}$ applied at the site. However, the result indicated that there was corresponding increase in Moringa yield with increase in nitrogen level application. The highest level (150 $\mathrm{Kg} \mathrm{N} \mathrm{ha-1}$ ) produced higher fresh and dry leaf yields, as compared to 100 and $50 \mathrm{Kg} \mathrm{N}^{-1}$ levels which also significantly produced higher yields compared to the untreated control $\left(0 \mathrm{Kg} \mathrm{ha}^{-1}\right)$ and this was in line with what was obtained by Matallawa (2012) and Radovich (2009) who reported positive yield responses of Moringa at fertilization rates of $350 \mathrm{Kg}$ $\mathrm{N} \mathrm{ha}{ }^{-1}$. Fuglie and Sireeja (2010) supported this in their report which stated that nitrogen application increase the yield of Moringa leaf of up to three folds.
The harvest interval significantly increase the fresh and dry leaf yields of Moringa ( $\mathrm{t} \mathrm{ha}{ }^{-1}$ ) with highest means of 46.03 and $12.32 \mathrm{t} \mathrm{ha}^{-1}$ fresh and dry leaf yields respectively obtained with 4 weeks harvest interval. The result was similar to that of Amaglo et al. (2006) who reported significant yield of Moringa leaf when harvested at 4-5 weeks harvest interval, after the initial harvest at 60 days after sowing. This indicated that leafy vegetables harvest interval plays a vital role in their yields. Though, the highest yields were obtained with 4 weeks harvest interval which could be due to more time allowed for leaves growth and development the finding agreed with Palada and Chang, (2003) who reported that harvesting of Moringa young edible shoots is possible at every two to three weeks harvest interval in Moringa plantation with nitrogen fertilization.

\section{CONCLUSION}

The study showed that nitrogen and harvest interval significantly affected the leaf yield of Moringa, when nitrogen level was held constant at 50,100 and 150 $\mathrm{Kg} \mathrm{ha}{ }^{-1}, 4$ weeks harvest interval produced significantly higher yield values throughout the harvesting periods with the highest values of 47.91 and $12.09 \mathrm{t} \mathrm{ha}^{-1}$ fresh and dry leaf yield respectively obtained with $150 \mathrm{Kg} \mathrm{N} \mathrm{ha}^{-1}$, whereas the lowest fresh and dry yields of 5.03 and $2.84 \mathrm{t} \mathrm{ha}^{-1}$ were obtained with the untreated control and 2 weeks harvest interval. Based on this study it can be concluded that farmers in the area of study should apply $150 \mathrm{~kg} \mathrm{~N} \mathrm{ha}^{-1}$ and harvest interval of 4 weeks after the initial general harvest at 12 WAS for high yield and good quality of Moringa leaf. 
Effects of Nitrogen levels on plant height $(\mathrm{cm})$, stem diameter plant ${ }^{-1}(\mathrm{~cm})$ and number of branches plant ${ }^{-1}$ of $_{\text {Moringa during }}$ 2011/2012 dry season at BUK

\begin{tabular}{|c|c|c|c|c|c|c|c|c|c|}
\hline \multirow[b]{2}{*}{ Treatment } & \multicolumn{3}{|c|}{ Plant height } & \multicolumn{3}{|c|}{ Stem diameter } & \multicolumn{3}{|c|}{ Number of branches } \\
\hline & 4 WAS & 8 WAS & 12 WAS & 4 WAS & 8 WAS & 12 WAS & 4 WAS & 8 WAS & 12 WAS \\
\hline \multicolumn{10}{|c|}{ Nitrogen(kg ha-1) } \\
\hline 0 & $8.89 b$ & $16.36 \mathrm{~d}$ & $42.00 d$ & $1.65 c$ & $3.50 \mathrm{~d}$ & $5.90 d$ & $7.75 b$ & $10.50 d$ & $14.17 d$ \\
\hline 50 & $9.01 \mathrm{~b}$ & $37.80 \mathrm{c}$ & $65.50 c$ & $1.75 b c$ & $4.67 c$ & $7.24 \mathrm{C}$ & $7.75 b$ & $13.08 \mathrm{c}$ & $16.67 c$ \\
\hline 100 & $9.08 \mathrm{~b}$ & $44.85 b$ & $86.26 b$ & $1.93 a$ & $5.86 \mathrm{~b}$ & $10.86 \mathrm{~b}$ & $8.67 a$ & $14.50 \mathrm{~b}$ & $18.42 b$ \\
\hline 150 & $9.89 a$ & $53.03 a$ & $105.54 a$ & $1.89 a b$ & $6.98 \mathrm{a}$ & $12.15 \mathrm{a}$ & $8.50 a$ & $15.25 \mathrm{a}$ & $21.33 a$ \\
\hline SE+ & 0.300 & 1.611 & 3.200 & 0.093 & 0.180 & 0.810 & 0.401 & 0.510 & 0.564 \\
\hline
\end{tabular}

Means followed by the same letter(s) are not significantly different at $5 \%$ level of significance using DMRT

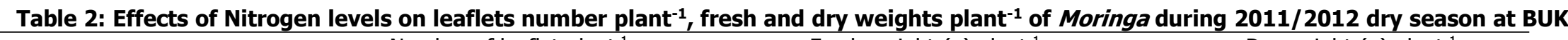

\begin{tabular}{|c|c|c|c|c|c|c|c|c|c|}
\hline \multirow[b]{2}{*}{ Treatment } & \multicolumn{3}{|c|}{ Number of leaflet plant ${ }^{-1}$} & \multicolumn{3}{|c|}{ Fresh weight (g) plant $^{-1}$} & \multicolumn{3}{|c|}{ Dry weight (g) plant ${ }^{-1}$} \\
\hline & 4 WAS & 8 WAS & 12 WAS & 4 WAS & 8 WAS & 12 WAS & 4 WAS & 8 WAS & 12 WAS \\
\hline \multicolumn{10}{|c|}{ Nitrogen $\left(\mathrm{kg} \mathrm{ha}^{-1}\right)$} \\
\hline 0 & $48.3 c$ & $102.3 d$ & $550.3 d$ & $1.12 b$ & $8.83 d$ & $21.45 d$ & $0.33 b$ & $3.97 d$ & $6.47 d$ \\
\hline 50 & $51.7 \mathrm{bc}$ & $446.8 \mathrm{c}$ & $845.4 \mathrm{C}$ & $1.18 \mathrm{~b}$ & $26.08 \mathrm{c}$ & $41.95 \mathrm{c}$ & $0.36 \mathrm{~b}$ & $7.71 \mathrm{c}$ & $13.32 \mathrm{c}$ \\
\hline 100 & $54.0 \mathrm{~b}$ & $586.7 b$ & $1114.3 b$ & $1.12 b$ & $30.05 b$ & $62.34 b$ & $0.44 a$ & $9.19 b$ & $23.11 b$ \\
\hline 150 & $58.3 a$ & $687.2 \mathrm{a}$ & $1159.2 a$ & $1.50 a$ & $40.98 a$ & $109.28 a$ & $0.51 a$ & $10.51 a$ & $31.30 a$ \\
\hline SE+ & 3.19 & 38.28 & 91.65 & 0.150 & 1.340 & 6.940 & 0.062 & 0.693 & 5.370 \\
\hline
\end{tabular}

Means followed by the same letter(s) are not significantly different at 5\% level of significance using DMR

Table 3: Effects of Nitrogen levels and harvest Interval on total fresh and dry leaf yields ( $t$ ha- ${ }^{1}$ ) of Moringa at BUK

\begin{tabular}{lll}
\multicolumn{1}{c}{ Treatments } & Fresh harvest & Dry harv \\
\hline Nitrogen $\left(\mathrm{kgha}^{-1}\right)$ & & \\
0 & $11.708 \mathrm{~d}$ & $3.448 \mathrm{~d}$ \\
50 & $21.738 \mathrm{c}$ & $6.795 \mathrm{c}$ \\
100 & $31.879 \mathrm{~b}$ & $8.320 \mathrm{~b}$ \\
150 & $38.057 \mathrm{a}$ & $10.211 \mathrm{a}$ \\
$\mathrm{S} . \mathrm{E} \pm$ & 1.0020 & 0.2222 \\
Harvest Interval (weeks) & & \\
2 & $9.931 \mathrm{c}$ & $3.590 \mathrm{c}$ \\
3 & $21.576 \mathrm{~b}$ & $6.426 \mathrm{~b}$ \\
4 & $46.029 \mathrm{a}$ & $12.317 \mathrm{a}$ \\
$\mathrm{S} . \mathrm{E} \pm$ & 0.8679 & 0.1925 \\
Interaction & & \\
$\mathrm{N} x \mathrm{HI}$ & $* *$ & $* *$ \\
\hline
\end{tabular}

Means followed by the same letter are not significantly different at $5 \%$ level of significance using DMRT, $* *$ Significant at $1 \%$. 
Table 4: Interaction between nitrogen levels and harvest interval on total fresh and dry leaf yield ( $t$ ha- ${ }^{\mathbf{1}}$ ) of Moringa at BUK

\begin{tabular}{|c|c|c|c|c|c|c|}
\hline \multirow[b]{2}{*}{ Harvest interval (weeks) } & \multicolumn{3}{|c|}{ Fresh } & \multicolumn{3}{|c|}{ Dry } \\
\hline & 2 & 3 & 4 & 2 & 3 & 4 \\
\hline \multicolumn{7}{|l|}{ Nitrogen $\left(\mathrm{kgha}^{-1}\right)$} \\
\hline 0 & $5.030 \mathrm{j}$ & $8.636 \mathrm{~h}$ & $15.848 \mathrm{e}$ & $2.835 \mathrm{k}$ & 4.467h & $5.952 f$ \\
\hline 50 & $6.940 \mathrm{i}$ & $11.060 \mathrm{~g}$ & $23.652 c$ & $3.382 \mathrm{j}$ & $5.405 \mathrm{~g}$ & $7.828 c$ \\
\hline 100 & 9.610h & $18.035 d$ & $30.850 b$ & $4.070 \mathrm{i}$ & $6.692 \mathrm{e}$ & $9.075 b$ \\
\hline 150 & $13.683 f$ & $23.503 c$ & $47.918 a$ & $4.443 \mathrm{~h}$ & $7.395 d$ & $12.090 \mathrm{a}$ \\
\hline SE \pm & & & 0.9974 & & & 0.7422 \\
\hline
\end{tabular}

Means followed by the same letter are not significantly different at 5\% level of significance using DMRT.

\section{REFERENCES}

Amaglo ,N. K., Timpo, G. M., Ellis, W. O. and Bennette R. N. (2006). Effect of Spacing and Harvest Interval on the Growth and Leaf Yield of Moringa (Moringa oleifera Lam), a Leafy Vegetable Crop. (anglophone group). Kwame Nkrumah University of Science and Technology Accra, Ghana, November 16-18. http://www. Moringafarm.com

Anonymous, (2008). Moringa. Retrieved on $15^{\text {th }}$ February 2011 from http://www. Moringa. comjournals.org/AJB.

Auwalu, B .M. (2009). Agronomic Management Practices for Commercial Production of Moringa (Moringa oleifera Lam). Unpublished Paper Presented at Two-day Workshop on Sustainable Production and Commercialization of Moringa at Imam Wali Hall Kano Nigeria.

Dash S, and Gupta N. (2009). Effect of inorganic, organic and Biofertilizers on growth of hybrid Moringa oleifera (pkm) .Acad. Journal .plant science 2(3); 220221. ISN 1995-8586 IDOS. Publishers.

Duncan, D.B. (1955): Multiple Range and Multiple F-Test Biometrics 11:1-42

Fahey, J.W. (2005).Moringa oleifera. A Review of the Medical Evidence for its Nutritional Therapeutic Prophylactic Properties. Part 1. Trees for Life Journal 1:5 pp54-67.

Fuglie, L.J. and Sreeja, K.V. (2010). Cultivation of Moringa. Retrieved on $3^{\text {rd }}$ February 2010 from http://www. Moringafarm.com

Genstat (2011). Release 10.3DE. VSN. International , 5. The Waterhouse Street, Hemel UK. Heampstead, Heartfordshire HPI IES

Grubben, G.J.H. and Denton, O.A. (2004). Plant Resources of Tropical Africa 2. Vegetables. PROTA Foundation Wageningen, Netherlands/Bachuys Publishers, Leiden, Netherlands/CTA, Wageningen, Netherlands. 668pp.
Kalb, T. and Kuo, G. ( 2002). AVRDC report (2001). Asian Vegetables Research and Development Centre, Shanhua, Tainan, Taiwan. Vii + 155pp. AVRDC. Publication 02-542.

Keay, R. W. J. (1959). An outline Of Nigerian vegetation, $3^{\text {rd. }} . p p$ 22-30. Federal Government Printers, Lagos Nigeria.

Matallawa D.M. (2012) Effects of Manure and NPK Fertilizer on Growth and Leaf Yield of Moringa (Moringa oleifera Lam) in the Sudan Savannah of Nigeria. M.Sc Dissertation submitted to the Department of Agronomy, BUK. Pp 65-102.

Muhammad, H. (2008). The Blessing Called Zogale: Moringa Tree Prevent 300 Diseases. Daily Trust Newspaper Nigeria, $17^{\text {th }}$ June http://www.dailytrust.com

Olivier, C. (2009) Intensive Moringa oleifera Caltivation In the North Senigal. Retrieved on $3^{\text {rd }}$ February, 2010 from www.syfia.com/fr/artcle

Palada, M.C. and Chang, L.C. (2003). Suggested Cultural Practices for Moringa International Cooperation Guide. Asian Vegetable Research and Development Centre. Publication No. 03-545-5pp.

Radovich, T. (2009).Farm Forestry Production and Marketing Profile for Moringa (Moringa oleifera. Lam). E.N Elevitch C.R. (ed) Speciality Crops for Pacific Island Agroforestry. Permanent Agriculture Resource (PAR), Holualoa, Hawaii http://www.agroforestry.net/scps

Samuel, R. A. (1980) Nitrogen. Illinois. Agricultural Experiment Station. USA. Pp 452- 455 